\title{
ARTIFICIAL INSEMINATION IN THE CONTEXT OF ISLAMIC BIOETHICS
}

\author{
Gamar Khanim Javadli, Ph.D. \\ Deputy Chair, Caucasus Muslim Board, Baku, Azerbaijan \\ ORCID ID: https://orcid.org/0000-0001-6229-2860
}

\section{DOI: https://doi.org/10.31435/rsglobal_conf/30112020/7272}

\begin{abstract}
In the process of advancing medical science, new concerns have arisen relating to artificial insemination. Artificial insemination, as a subject of both secular and Muslim bioethics, should be investigated from different aspects. It is important to consider whether artificial fertilization is halal from the point of view of Islamic religious ethics, and to compare the decisions made by the Islamic Fiqh Academy regarding artificial insemination with the original sources of Islam. The main conclusion of the article is that the position of the Muslim theological school should be developed and promulgated, since bioethical problems can have serious consequences for the life of a person, family and society. The article is one of the components of the author's research on the theoretical and practical basis of Islamic bioethics. The methodological structure of the article has a theoretical and practical nature for the study of such areas of Islam as ethics, fiqh and bioethics.

Keywords: artificial insemination, heterologous and homologous means, intellectual and religious justification, fatwas of the Fiqh Academy.
\end{abstract}

Introduction. Bioethics is the field of science that forms a new starting point of philosophical thought. Its formation and development are closely related to the transformation of traditional and medical ethics as a whole. Interest in bioethics is foremost an indication of the global interest across modern societies that creates a number of challenges that require significant spiritual and legal regulation in the area of human rights, as well as testing of new technologies and medicinal products on humans.

It should be noted that with significant achievements made in medical, biological and methodological research during 1965-1980, an unprecedented technological revolution took place in the world of science. Although these achievements were of extraordinary significance to mankind, they raised a number of new moral and ethical issues.

Even as artificial insemination is advancing as a field of modern medicine, human embryos developed in research are terminated. After the egg and sperm cells taken from the mother and father candidate are combined in a laboratory setting to successfully complete the in vitro fertilization, some of these embryos are transferred to the womb of the mother candidate, while others are stored frozen. Only one of the embryos transferred to the mother's womb will develop normally, while the embryos that do not develop are terminated through abortion. Frozen embryos perish if not used within 5 years. Furthermore, live human embryos are used in research and experiments for artificial insemination. Scientists could have never imagined this type of research in the past.

The simplified approach to artificial insemination has resulted in a similarly relaxed approach to human embryos. This method allows parents not only to choose the gender of their child or even identify the most ideal time for birth, but also encourages opportunities for further research in eugenics. Finally, in our developed world, artificial insemination has become a highly lucrative practice for doctors. In truth, with material interests on one end of the scale, the value of human life is undermined on the other.

All medical projects, particularly those that are based on artificial insemination, along with genetic studies are seeking the answer to one important question: should every innovation that has become technically possible be allowed to proceed?

Currently, there are talks of establishing a scientific tribunal that would resolve these disputed issues. Some call for a set of new laws to regulate scientific research, while others avoid publishing in scientific journals in a manner that could cause moral objections. Rising from controversial processes as one of the most popular sciences of the 20th and 21st centuries, bioethics emerges with global questions and answers for society and mankind.

The attitude of the world religions toward the most important issues in bioethics - artificial insemination, cloning, abortion, euthanasia, experiments on patients, etc., has never been simple. It is 
important to point out that disagreement on these issues reigns among different religions and sects. The Christian faith, particularly the Catholic and Eastern Orthodox churches, hold broad views on this matter. The church generally keeps all processes in the field of biomedical innovations under control and regularly prepares its recommendations for modern medical innovations.

There are noted similarities in Christianity and Islam's attitudes towards medical and religious ethics. The protection of human dignity - expression of human rights, freedom of choice and will, hold the same meaning in both religions. In this respect, Islam gives utmost preference to human free will. The attitude in Islam towards bioethics is closely related to its attitude towards mankind. What distinguishes Islam from other world religions is that it provides and protects an individual's identity, merit, rights and in particular, women's rights, both on the basis of Shari'ah and secular laws.

The separate interpretation of Islamic jurisprudence in terms of exclusion, opinion, comparison and ijtihad of the secular bioethical problems emerging in modern times aims to demonstrate the attitude of different sects and movements towards popular morality. In order to solve the new ethical problems created by biomedical technologies, today's Muslim jurists and fiqh scholars hold regular meetings and prepare certain judgments and decisions. The scope and effect of these provisions and decisions are of great interest to the Muslims of Azerbaijan.

The contemporary period we are in is a period of contradictions and scientific developments that are closely related to each other. As science progresses, as in all areas of life, judicial and legal precedents occur in the religious sphere, which creates discrepancies between science and religion. The only amiable solution to these types of conflicts is in finding answers to these problems.

One of the new subjects that have emerged as a result of increasing success in medicine is artificial insemination. Of course, because rights in Islam are regulated under Shari'ah law, no lawyer or legal expert can legitimize these controversial current issues without consulting Islamic law. To that extent, the faqihs must first consider such matters from the perspective of Shari'ah law, so that legal experts can then ensure that necessary laws are put into effect according to these regulations.

It is important to note that the issue of artificial insemination is very broad, deep and controversial, so we will attempt to review it in a thorough, comprehensive manner. Since this is a topic of interest in secular bioethics, but also particularly in Muslim bioethics, we will examine it in 3 steps.

In the first step, we will review the definition of artificial insemination, as well as its history, including the first country it was performed in and what living creatures were used in the initial experiments. Subsequently, we will review whether this issue is halal in terms of Shari'ah law and the decisions made by the Islamic Fiqh Academy regarding artificial insemination. In the second step, we will consider the various options for artificial insemination and the respective position of the fakihs in regards to each option. In the third step, we will examine the position of Islamic lawyers on artificial insemination and present the conclusion of this issue.

Research Methods. We can define artificial insemination as the fertilization of female and male reproductive cells outside of the body. In other words, the process, without a sexual act between a man and a woman, but with egg cells from the woman who will become the mother combined with the sperm cells of the candidate father in laboratory settings, subsequently placed in the mother's womb again, constitutes artificial insemination.

Artificial insemination was first performed in Russia. This event took place in the first half of the twentieth century, when Russian scientists practiced artificial insemination in sheep, cows, horses and pigs. In 1950, scientists first managed to freeze bull sperm to -79 degrees Celsius using liquid carbon dioxide and then to -196 degrees using liquid nitrogen. The scientists who were able to heat the frozen sperm to normal temperatures found that these sperm samples did not lose their effectiveness. Thus, artificial insemination of animals with donor sperm preserved over long periods of time was possible.

The first person to have applied internal insemination by artificial means and used a substitute mother was M. C. Chang of Boston, USA. He conducted this experiment on rabbits in 1959. The first attempt to conduct artificial insemination on humans was done by Robert Edwards in 1965. In 1978, after many previous failed attempts, Robert Edwards and Patrick Steptoe saw the birth of the first human child conceived by artificial insemination.

This process begins with the removal of the woman's egg cell out of the ovaries. On November 10, 1977, Dr. Patrick Steptoe placed mother candidate Lesley Brown's egg cells into a container prepared by Dr. Robert Edwards. After fertilization took place in the container and the 
zygote had developed sufficiently, Dr. Steptoe placed the blastula in Lesley Brown's womb on November 12, 1977 and on July 25, 1978, in news that resonated all across the world, Louise Brown, the first child successfully conceived through artificial insemination, was born.

The actual insemination process is divided into two types: homologous and heterologous. The homologous method is applied when the woman's partner has sperm cells that are healthy, but the woman cannot conceive by natural means for physical or psychological reasons. In this method, sperm cells taken from the man are released into the woman's uterus.

Artificial insemination has been the subject of debate and discussion among Islamic scholars since it was first introduced. Previously, several well-known Shia faqihs had found this practice to be unacceptable. Today, however, the majority of the Shia faqihs state that this is permissible (halal). The reasoning of those who argue that artificial insemination is permissible (halal) is based on both sperm cells and egg cells belonging to the spouses themselves and only the fertilization process being solved by artificial means. There is no evidence that this situation is haram. The intellectual and Shari'ah perspective also find this is permissible. However, haram activities, such as adultery or the transfer of sperm cells into the womb of another woman are not considered.

The position of the Sunni (Hanafi) faqihs regarding homologous fertilization is different. Although the majority of Sunni faqihs stated that this matter was permissible on the condition that certain rules are applied, a small number of faqihs, such as Sheikh Ahmad al-Haji stated that this was haram. The main argument of those that view artificial insemination as permissible is that married couples are able to have children this way and that the birth of the children strengthens the love and bond between them. The argument of the faqihs on the opposing side is that a child can only come into the world as a result of sexual intercourse. If a child cannot be conceived through sexual intercourse, then that is Allah's will, or to put it another way, artificial insemination is to contrary to Allah's will and it eventually leads to shirk (idolatry), which is one of the greatest sins. They defend their ideas with this verse of the Qur'an: "To Allah belongs the dominion of the heavens and the earth. He creates what He wills (and plans). He bestows (children) male or female according to His Will (and Plan), Or He bestows both males and females, and He leaves barren whom He will: for He is full of Knowledge and Power." (Surah Ash-Shura, 49-50).

Heterologous fertilization is applied when no issues can be observed in the woman's fertility, while the male partner's sperm cells are not capable of making the woman pregnant. In this case, sperm cells from a third-party male (donor) are taken, prepared and then placed in the woman's uterus. The majority of Shia faqihs said that this type of artificial insemination is haram, while a small number have found it to be halal (permissible).

Those who argue that heterologous fertilization is haram associate it with the commandments given to men and women to protect themselves from haram, by referencing several surahs of the Qur'an (Surah Al-Mu'minun 5-7, Surah An-Nur 30-31, Surah An-Nisa 22-23, Surah Al-Ma'arij 29), as well as relying on the hadiths from the Imams. One of their verses on this subject is as follows: "Say to the believing men that they should lower their gaze and guard their modesty: that will make for greater purity for them: And Allah is well acquainted with all that they do", "And say to the believing women that they should lower their gaze and guard their modesty." The relative nature of "lowering the gaze" is highlighted by the use of Arabic preposition min in these ayahs. This means that only one aspect of the gaze is considered haram, relative of the situation.

Those who view the heterologous method as unlawful, support their opinion with several hadiths, with the following two in particular:

1. Ali Ibn Salim had narrated the following saying of Imam al-Sadiq (a): "on the Day of Judgement, the most severe punishment will be given to the man who transfers his own nutfah (the sperm cell that has fertilized the egg cells) into the womb of another (namahram) woman." It is understood from this hadith that it is a great sin for a man to transfer his own nutfah (sperm) into the uterus of a namahram woman. The word nutfah mentioned in the hadith refers that the sperm cells of the man fertilizing the egg cells of the woman in the process of forming an embryo.

2. Imam al-Sadiq (a) had narrated The Prophet (SAWS) saying: "there is no greater sin in the presence of Allah than killing the prophet or imam, destroying the Kaaba which Allah has chosen as the Qibla for his servants, and transferring a man's own nutfah into the womb of another woman." 
This hadith also makes it clear that it is a sin for a man to transfer his own sperm cells into another woman's womb. This hadith covers the transfer of sperm to the womb of another woman, regardless of the way that it happens, as absolutely haram and a great sin. Many modern Shia faqihs have submitted other evidence that artificial insemination is haram.

It should be noted that the Sunni faqihs believe that the heterologous method of artificial insemination is haram. The following are two key arguments on this position:

1. This act, beneath the level worthy of humanity, stooped down to the level of animals and plants, is at the same time, a great sin and considered as grave as adultery. Because the goal of both is the deliberate transfer of the male sperm cell into the woman's uterus. This type of artificial insemination would also not be approved from the perspective of child adoption, forbidden in Islam. Just as with adoption, it is at the very least established that a child has biological parents, so in this case the paternity is not firmly established and a third party becomes involved.

2. "Call them by (the names of) their fathers." Referring to this verse, the Sunni faqihs pointed out that children are ascribed to their own fathers. In heterologous insemination, a child conceived from another man's sperm cells is ascribed to the woman's actual partner. However, the wife's partner is aware that the child is not his and cannot accept the child as such.

The Islamic Fiqh Academy has made several resolutions regarding artificial insemination. The Islamic Fiqh Academy, which had been founded by the Organization of the Islamic Conference (currently called the Organization of Islamic Cooperation), was established on the basis of the decisions made at the 3rd Summit of Heads of State and Governments of Islamic Countries, convened in Saudi Arabia on 25-28 January 1981. The aim of this institution, headquartered in the city of Jeddah, is to aid with matters in the field of Islamic law and to find solutions in accordance with Islamic law to problems that arise in modern times.

One of the main issues discussed and deliberated by the Islamic Fiqh Academy is the subject of artificial insemination. Thus, at the VIII Assembly of the World Islamic Unity Center in Mecca (27 Rabi' al-Akhir 1405 - 7 Jumada al-Awwal 1405 / 19-28 January 1985), the following decisions regarding artificial insemination were made:

The methods of artificial insemination currently known are as follows:

1. the sperm cells of the husband are used to fertilize the egg cells of a third-party female and the developed embryo is placed in the womb of the wife.

2. a wife's egg cells are fertilized with a third-party male's sperm cells and the embryo is placed in that woman's own womb.

3. An embryo developed from laboratory-based fertilization of a couple's own egg and sperm cells is placed in the womb of a surrogate mother.

4. An embryo developed from laboratory-based fertilization of third-party female egg cells by third-party male sperm cells is placed in the womb of a woman

5. The husband's sperm cells are used to fertilize his wife's egg cells in a laboratory setting and are subsequently placed in the womb of his second spouse

6. An embryo from fertilization of a woman's own egg cells by her husband's sperm cells is developed in a laboratory setting and subsequently placed back in the woman's womb.

7. The sperm cells of the husband are collected and artificially inserted into the wife's womb, resulting in an internal fertilization of the egg cells

Taking into account the above articles, the Assembly passed the following resolutions:

The first five methods are in contradiction with religious principles, interfering with natural generational development, as well as raising uncertainty with the nature of motherhood, etc. and are by all means considered haram.

At the same time, the Islamic Fiqh Academy, emphasizing the need for action when appropriate, found that, if necessary, the sixth and seventh methods are permissible.

The most recent provisions on artificial insemination were adopted at the second meeting of the Eurasian Fatwa Assembly held in Istanbul in 2017, under the coordination of the presidency of Religious Affairs of the Republic of Turkey. According to a resolution passed by the Assembly, "...in cases of medical necessity, there is no harm in inseminating the egg cells of a woman with the sperm cells of her lawful husband." (3;6) The use of the sperm cells belonging to a man other than the lawful husband, in fertilization of the woman's egg cells and subsequent assurance of her pregnancy, is not 
permissible, as it incorporates elements of adultery and is offensive to natural human instincts. This method is only appropriate when breeding animals.

Today, new milestones have been achieved in the field of artificial insemination and for spouses who cannot have children naturally, new methods and techniques have been developed. Among these, the most widely applied method involves inseminating the egg cells with the sperm cells in a laboratory setting and placing the fertilized cell back in the woman's womb. This treatment is essential to women who cannot otherwise get pregnant naturally. There is absolutely no difference between the normal fertilization of the egg cells with sperm cells of spouses and a method where this fertilization occurs externally and the embryo is subsequently placed back in the womb. This is on the condition that the spouses any other way cannot conceive a child.

Outside of the scenario described above, any case where a third-party element is involved, such as use of the sperm cells, egg cells or the uterus of a person who is not one of the spouses, is not permissible. From the perspective of Islam, a legitimate child must have a relation to its parents both through sperm and egg cells, and the womb it grows in.

\section{Legal examination of artificial insemination.}

As noted at the outset, issues such as a child's custody, marriage and inheritance are put within the context of the child's lineage. The lexical meaning of the word nasab (lineage) implies relationship and dependence and is generally used with reference to ancestral kinship. From a legal standpoint, there are several definitions for the word nasab. The late Dr. Imami had defined nasab as follows: "Lineage is something that occurs as a result of sexual relationship between a man and a woman. A child born on the account of such a relationship signifies the blood ties between the man and the woman."

None of these definitions fully reveal the essence of nasab. That is, according to these definitions, it is not understood whether lineage is natural or relative. Since lineage has not been defined in Shari'ah law, this issue has been left up to the community to adjudicate.

From a medical standpoint, the formation of the embryo is influenced by the father, meaning that it is related to the sperm cells. In society, lineage is formulated by way of physiological fecundation. There are verses and hadiths that also support this. For example, a verse from the Qur'an says: "It is He Who has created man from water: then has He established relationships of lineage and marriage."

As we can see from the verse, there are kinship relations between people created from the same seed. The society also adopts this view when referring to family relationships. In reality, this is how an embryo develops and forms. However, unfeasible matters, such as adopting someone, etc. have no ancestral basis to them.

In addition, a number of thoughts were expressed regarding the child's relation to the mother. One of the main thoughts is that at the basis of this relationship is the act of birth. Both in terms of the lexical meaning and the generally accepted opinion, a mother is a woman who has given birth to a child who was conceived of her. Therefore, a newborn's mother is the woman who was pregnant with that child and gave birth to it.

Those who disagree with this have made a number of statements against the aforementioned claim, and we are referring to only one of them. In the following verse, Allah calls the woman who gave birth to a single human a mother, but it is not stated that a woman who did not bear the child cannot be considered his mother as well. For example, although the "milk mother" (a wet nurse, a woman employed to provide suckle to another woman's child) is not the woman who became pregnant and gave birth to the child, she is also defined as a mother in the Qur'an.: "Prohibited to you (For marriage) are: Your mothers, daughters, sisters; father's sisters, Mother's sisters; brother's daughters, sister's daughters; foster-mothers (Who gave you suck), foster-sisters; your wives' mothers; your stepdaughters under your guardianship, born of your wives to whom ye have gone in, no prohibition if ye have not gone in; (Those who have been) wives of your sons proceeding from your loins; and two sisters in wedlock at one and the same time, except for what is past."

Another criteria in establishing a relationship of a child to its mother involves the egg cells. Those holding this view equate motherhood and fatherhood. That is, the mother of a child is the woman who plays a role in the formation of the embryo, being the source of the egg cells that are combined with the sperm cells to develop the foetus. The nutrients absorbed by the woman serve the development of the child. From a medical point of view, the formation of the embryo is the result of the merger of the sperm cells of the man and the egg cells of the woman. Many verses of the Qur'an confirm this idea: "Verily We created 
Man from a drop of mingled sperm..." and "It is He Who has created man from water: then has He established relationships of lineage and marriage: for thy Lord has power (over all things)."

Another criterion of the child's relationship to the mother is that the mother exclusively provides both the uterus and egg cells. The view on this is that both the woman who is the source of the egg cells responsible for forming the embryo, and the woman whose uterus the embryo is placed in, are considered the mother of the child.

With the subject of artificial insemination, enriched with today's bioethics, framed within the sensitive approach of our society and the permissibility within Shari'ah law, being sufficiently important, it becomes very difficult to accept one of the aforementioned views over others. Both genetically, and from the viewpoint of our society, having an embryo formed from a woman's egg cells be placed in another woman's womb does not deprive the woman who provided the egg cells of being the mother. However, on the other hand, it is not appropriate to dismiss the woman who carries the child in her womb for months and is literally connected in body with it. In particular, many verses of the Qur'an show that Allah sees as separate the stages between the formation of the embryo and the final development of a child. "Then We made the sperm into a clot of congealed blood; then of that clot We made a (foetus) lump; then we made out of that lump bones and clothed the bones with flesh; then we developed out of it another creature."

Allameh Tabataba'i in interpreting this verse, had written: "In this verse, Allah wants to point out that this flesh-and-bone creature is entering a new phase. So much so that this lifeless, ignorant, helpless being transforms into a living being capable of holding knowledge and power."

From various verses and hadiths relating to this subject, we conclude that a child in this situation is connected to both women. Therefore, both the woman who provided the egg cells for the embryo and the woman whose womb the embryo developed in are considered the mother of the child.

\section{Various options for artificial insemination}

Here, we will review the various options for artificial insemination, while at the same time, considering the position of the various Islamic scholars on the matter:

\section{Fertilization of a woman's egg cells with her husband's sperm cells}

In some circumstances, the sperm cells of a husband and the egg cells of his wife are not fertilized naturally, so this may be achieved medically in a laboratory environment, after which the embryo is transferred to the woman's uterus. The foetus continues its development in the woman's womb. It appears that all the faqihs consider this process halal, as there is no evidence to any parts of it being haram. Due to some of its potentially questionable aspects, based on the legal and intellectual deliberation methods within Usul Al-Fiqh, this process is considered halal conditionally, provided the sperm cells are not obtained in a manner considered haram, such as masturbation or external visual or physical stimulation.

This type of artificial insemination has been considered halal as it does not involve any elements of adultery, and there is nothing forbidden in the process of combining the male sperm cells and the egg cells of his wife in a laboratory environment. A child conceived this way will be a fullfledged child of the parents, just as the spouses will be the rightful parents of the child, with issues of lineage and inheritance being naturally addressed.

"The fertilisation of a man's sperm cells with the egg cells of own wife is lawful, but the sperm cells must not be obtained in forbidden ways. If a child is conceived through the artificial insemination process as described, the newborn will be considered a lawful child of the parents. Even if aspects of obtaining sperm cells are haram (for example, by way of masturbation), the child that is conceived as a result will still be considered the legitimate child of the parents. However, the man is guilty because of engaging in masturbation."

The fatwas of the Mujtahideen, such as Mohammad Reza Golpaygani, Sheikh Yousef Saanei, Mohammad Momin, Mohammad Yazdi and Sayyid Mohammad Sadeq Rohani, affirm this idea.

\section{Transfer of the embryo from one woman's uterus to another woman's uterus}

This option consists of the following elements:

a) Biologically, there are no problems with either of the spouses, that is, there is no obstacle to the fertilization of the sperm cells of the husband and the egg cells of the wife and the forming of the foetus. However, due to medical conditions of the wife, such as diabetes or thalassemia, the foetus cannot be kept viable in the uterus and results in a miscarriage. With the latest advances in medicine, the occurrence of this scenario has been considerably reduced. 
b) the sperm cells and the egg cells of the spouses are combined in a laboratory environment and transferred to the womb of a third party female. In Shari'ah point of view, this can be considered rental of the uterus.

Ayatollah Khomeini was asked: "some women, due to health issues and for other reasons, cannot carry the foetus in their wombs and suffer miscarriages. In such a case, if the foetus is developed in the uterus of another woman, can the child be returned to the biological parents, considering the foetus has developed in a rented uterus until the birth". Ayatollah Khomeini replied: "If this example contains no elements of haram, the fact that the embryo developed in the uterus of a third party female does not present a challenge. If the foetus is formed from the spouses' sperm cells and egg cells, the child belongs to them."

c) In some instances, the woman may not have viable egg cells, and so egg cells of another woman are transferred to the woman's uterus, which are then fertilized with the sperm cells of the first woman's husband in the course of sexual intimacy. According to some scholars, based on the hadiths referenced earlier, the fertilization of a third party female's egg cells with the husband's sperm cells is considered haram. However, the scholars who argue that this is not haram have clarified that the issue referenced in the hadiths is with the transmission of the man's sperm into the third party female's uterus. Therefore, these hadiths should not be referenced in relation to a scenario where a husband's sperm cells fertilize a third party female's egg cells in the womb of the lawful wife. It should be noted that as the egg cells of the third party female are transferred to the womb of the wife, these cells integrate with the wife's body and are eventually considered her own.

The process of transferring the embryo into another woman's womb, also known as surrogacy, is one of the issues that have become relevant in recent times. Over the past 20-30 years, several various versions of this process have emerged. We will focus on one.

With both the husband and wife being in adequate health, the husband's sperm and the wife's egg cells being within normal parameters, but due to medical concerns with the wife's body, such as diabetes or thalassemia, the wife may have difficulty carrying the embryo to term. In this case, the transfer of the foetus to another woman's womb can happen in the following two cases:

1. The woman into whose womb the embryo is transplanted can become mahram to the man, there is no harm in being close to him. In this instance, the opinion of all Islamic scholars, there is no legal justification for considering the embryo transplantation to be haram. Because the man wishes to transfer his own sperm cell into the womb of the woman who is privy to him, we can see that this method is not haram.

2. The embryo is placed in the womb of a woman, closeness with whom would be haram for the man. The scholars could not come to a common decision regarding this, some considering this lawful and some say that it is haram.

Those advocating that it is permissible to transplant the embryo into another woman's womb defend their view on the basis that protection and preservation of the embryo is of utmost importance. The embryo should not be allowed to be destroyed under any circumstances. If there is no argument that the transfer of the embryo to another woman's womb is haram, the situation is considered lawful in accordance with the rules of justification within Usul al-Fiqh. In the interests of erring on the side of caution, and since there is some evidence that this is haram in Shari'ah, a further, deeper review of the issue is necessary.

The muftis have expressed their views on the subject. Mohammad Taqi Bahjat answered the question posed to him regarding permissibility of transferring embryos or sperm cells to a third-party woman's womb as follows: "if there are no pre-requisites with haram elements in this matter, then there is no wrong."

Mohammad Yazdi answered this question as follows: "after fertilizing male and female reproductive cells in a laboratory environment, it is lawful to transfer the cell that is formed into another woman's womb regardless of her marital status. This can not be considered haram. Because this is neither adultery, nor the transfer of the male's own sperm cells into the womb of a namahram woman."

Those who view this matter as haram have drawn attention to several verses and hadiths, such as: "And say to the believing women that they should lower their gaze and guard their modesty." This verse commands believing women to protect their eyes and their honour (private parts) from haram. It appears to suggest that the woman can not leave her private parts at the disposal of her doctor or obstetrician. In this respect, the doctor's actions to transfer embryos into a woman's womb would be considered haram. If 
someone views this action involving lawful spouses as haram, it should be noted that some scholars view all forms of artificial insemination as unlawful, labeling them as unnatural and foreign.

Those who object to this claim feel that in protecting private parts of a woman from haram, the aforementioned verse only refers to protecting them from the sight of others. Based on this, the transplantation of a namahram man's sperm cells into a woman's womb naturally or through the artification insemination process is not a concern. The need to only protect private parts from being seen by others is also seen in the hadith of Imam al-Sadiq (a) narrated by Abu Basir. In that same hadith, Imam (a) says: "apart from this verse, in all the other verses in the Qur'an about guarding the private parts, the reference is to guarding against adultery "; This hadith was narrated in "Tafsir AlQummi" and "Tafsir Noor al-Thaqalayn", as well as in "Usul al-Kafi". There is no concern in the execution of the hadith narrated in "Tafsir Al-Qummi".

Yousef Saanei was of the view that transferring the embryo into another woman's womb is haram. He had noted the importance of avoiding these methods of reproduction, which are contrary to moral values. Fazel Lankarani, Hossein Noori-Hamedani and Abdul-Karim Mousavi Ardebili had also stated that this scenario is not allowed under Shari'ah law.

Conclusions. The position of Islamic scholars on artificial insemination.

The views of Islamic faqihs about artificial insemination can be grouped as follows:

1. All forms of artificial insemination by medical means being halal

Ayatollah Sayyid Ali Hosseini Khamenei, as well as Hassan Tabatabaei Qomi, Mohammad Yazdi and Sayyid Mohammad Mousavi are all in support of this view. Their main argument is that no verse in the Holy Qur'an or any hadiths indicate that this situation is prohibited. However, even those supporting this view caution staying away from using a third-party male's sperm cells in artificial insemination, as well as introduction of elements of haram during the process of artificial insemination.

\section{All forms of artificial insemination by medical means being haram}

Among those holding this view, Sayyid Mohammad Hadi Milani, as well as several prominent Sunni scholars have proclaimed artificial insemination to be absolutely haram, while Shaykh Muhammad Abdul Latif al-Farfour and Bakr Abu Zayd Mohammadsharif Ahmed only considered some aspects of artificial insemination to be unlawful. As the main evidence in support of their view, they reference "Your wives are as a tilth unto you; so approach your tilth when or how ye will", stating that reproduction must occur only as a result of natural sexual intercourse. According to this verse, men should only be intimate with their wives and offspring must only be produced as a result of this intimacy. Bringing a child into this world by other means (artificial insemination) is contrary to this verse of the Qur'an. In addition, verses such as " He is created from a drop emitted, Proceeding from between the backbone and the ribs" show that gushing nutfah (sperm) must enter the female uterus. This does not occur with artificial insemination. On the other hand, in situations unrelated to artificial insemination, the namahram (marriageable) man might see and touch a woman's body, under circumstances that on their own would be considered haram.

3. Artificial insemination by medical means between spouses being absolutely halal, artificial insemination involving a third-party man or woman being halal only under certain circumstances.

Some mujtahideen have ruled that the fertilisation of the husband's sperm cells and his wife's egg cells is absolutely halal. Mohammad Momin Qomi and Mohsen Harampanahi have served as guiding examples to the scholars who are of this view. They support their claim with references to hadiths that forbid a man's own sperm to enter the uterus of a woman who is not his wife, inferring from this that artificial insemination is not strictly forbidden. However, with regards to a third-party man's sperm cells being used to fertilize a woman's egg cells in a laboratory setting being considered haram, since there are basis for finding it unlawful, the provision has been made that it is not halal.

4. Artificial insemination by medical means strictly between spouses being absolutely lawful, while artificial insemination involving a third-party man or woman being absolutely forbidden.

The criteria for determining whether the fertilization process is halal or haram are the composition of the reproductive cells and the involvement of third-party donors. In the process of fertilizing egg cells with sperm cells, the matter of whether artificial insemination is lawful or unlawful has no relevance. Among the chief evidence referenced by the scholars of this opinion are ayahs, hadiths, the intellectual opinions and arguments expressed within Usul al-Fiqh, the philosophy on marriage rules, 
etc. Several prominent scholars, as well as Ayatollahs Khomeini, Montazeri and al-Khoei, can be cited for guiding examples on this issue. Among the Sunni scholars, Shaykh Mustafa Al-Zarqa, Abdullah Bassam, Abdusalaam Ibadi, Shaykh Abdelhalim and others are also of this opinion.

\section{Artificial insemination by medical means strictly between spouses and only under certain conditions being halal.}

Those supporting this view find artificial insemination to be lawful only on the condition that all the steps involved are by the spouses themselves and that this measure is taken out of great necessity. Even so, not all all types of artificial insemination, but only the intrauterine insemination (IUI) method is considered halal. Their reasoning is the same as the reasoning demonstrated in the second group described above. Although Shaykh Mustafa Zarga and Dr. Mohammad Ali Al-Bar referenced Sunni scholars who support this view, they did not disclose their names. It is noteworthy that the fatwa centers of Egypt and Jordan also support this theory.

Ayatollah Borujerdi, a Shia faqih, can also be added to the list of those supporting this view. He considered it permissible for a husband's sperm cells to be introduced to his wife's uterus, but only out of absolute necessity.

\section{halal or haram.}

6. No opinion being expressed on whether medically conducted artificial insemination is

Shaykh Abd al-Aziz ibn Baz, who presided over the VIII meeting of the Islamic Fiqh Academy (Hijri 1405), and one of the participants, Sheikh Bakr Abu Zayd, were in support of this opinion.

As we come to a close on the subject of artificial insemination, with the intent of obeying the commands Allah has given and the bans Allah has imposed, and in particular, "To Allah belongs the dominion of the heavens and the earth. He creates what He wills (and plans). He bestows (children) male or female according to His Will (and Plan)", "Or He bestows both males and females, and He leaves barren whom He will: for He is full of Knowledge and Power", it is most advisable to accept the will of the Supreme Creator.

Our conclusion is that because biotechnology and bioethics concerns have most serious consequences for the human life, the basis of family and society, the Muslim theological school of thought should be completely reviewed and informed on this subject. We must consider that biomedical concerns become increasinly complex, as they reflect both the complexities of the actual science behind them and the firm interests of some social groups. Therefore, while accounting for the rules of implementation of biological innovations, it is necessary to focus on the arising conflicts in their technological, economic, political and moral aspects and to correctly interpret the theoretical and experimental foundations of religious and ethical propositions.

\section{REFERENCES}

1. The Holy Qur'an, Revised English Translation by Yusuf Ali (1985).

2. Abdullayev A., Contemporary Medical Procedures From Islamic Perspectives. BIU, Zaqatala Branch, 2010

3. Eurasia Fatwa Meeting 2. Final Declaration. Istanbul. 20.02.2018. Letter \# 040/12 of TC Religious Services Advisor.

4. Bioethics, Medical Legislation and New Technologies / Article Thesis. AMEA Human Rights Institute, 2011

5. Karaman H., Halallar va haramlar [ Halal and Haram] // B.: "Ipekyolu" - 2011.

6. Guliyev M., Islamic Fiqh Academy. Modern Regulations and Their Analysis. BIU Zaqatala Branch. 2013.

7. Reproductive Health: Instances of Ethics Issues. UNESCO Bioethics Chair (Commission). Edition of AMEA Human Rights Institute. 2012

8. Dairi Ahmed, A new era in biomedicine: what is the position of Muslims?, website: www.islamonline.net

9. Mamedov B., Mamedov P., Mustafayeva A., Religious Studies. Moral and Legal Criteria in Bioethics. Nov 29, 2011

10. Fakher Ben Hamed, Muslim Moral, Medicine and Biotechnologies. Bioethics Commission of the Russian Federation for UNESCO, 2009.

11. Islamic Encyclopedia of Norms and Values. Basis of Fiqh According to Teachings of Imam Azam Abu Hanifah. 1st Edition. Istanbul: Erkam, 2013 